Alignment: Journal of Administration and Educational Management

Volume 1, Nomor 1, Juni 2018

e-ISSN : 2598-5159

p-ISSN : 2598-0742

DOI : https://doi.org/10.31539/alignment.v1i1.278

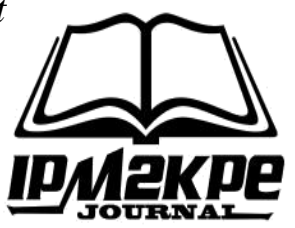

\title{
KONSEP KOMUNIKASI PENDIDIKAN DALAM ALQUR'AN SURAT LUKMAN
}

\author{
Ahmad Gawdy Prananosa ${ }^{1}$, Doni Pestalozi ${ }^{2}$, Adisel $^{3}$ \\ Sekolah Tinggi Keguruan dan Ilmu Pendidikan, PGRI Lubuklinggau ${ }^{1,2}$ \\ Institut Agama Islam Negeri Bengkulu ${ }^{3}$ \\ ahmadgawdynano@yahoo.com ${ }^{1}$
}

\begin{abstract}
ABSTRAK
Penelitian ini bertujuan untuk menelaah konsep komunikasi pendidikan dalam alqur`an surat Lukman. Penelitian ini dirancang menggunakan pendekatan kualitatif dengan menerapkan metode penelitian kepustakaan. Data yang digunakan dalam penelitian ini bersumber dari data primer dan data sekunder, adapun yang menjadi data primer adalah Naskah Al-Qur'an Surat Lukman dan didukung dengan hadisthadist Nabi yang relevan dengan permasalahan penelitian, sedangkan data sekunder bersumber dari buku-buku, majalah-majalah dan dokumen tertulis. Simpulan penelitian ini mengungkapkan bahwa konsep komunikasi pendidikan dalam Surat Lukman diindikasikan dengan suasana dialogis antara ayah dan anak dalam upaya untuk mencapai keselamatan hidup di dunia maupun di akhirat. Istilah dialogis disini menunjukkan bahwa adanya suatu unsur komunikasi antara dua orang, dalam hal ini ayah dan anak. Ayah berkedudukan sebagai komunikator atau pemakarsa gagasan dalam merencanakan suasana dialog tersebut. Sekaligus merupakan pihak yang mendengarkan (dalam umpan balik dialog) sehingga ia sekaligus menjadi komunikan.
\end{abstract}

Kata Kunci: Komunikasi Pendidikan, Al-qur`an Surat Lukman

\begin{abstract}
This study aims to examine the concept of educational communication in the Qur'an Lukman letter. This research was designed using a qualitative approach by applying library research methods. The data used in this study are sourced from primary data and secondary data, while the primary data are Al-Qur'an Letters Lukman and supported by the Prophet's traditions that are relevant to the research problem, while secondary data are sourced from books, magazines and written documents. The conclusion of this research reveals that the concept of educational communication in Lukman's Letter is indicated by the dialogical atmosphere between father and son in an effort to achieve life safety in the world and the hereafter. The term dialogic here shows that there is an element of communication between two people, in this case father and son. My father is a communicator or idea initiator in planning the dialogue atmosphere. At the same time it is the party that listens (in dialogue feedback) so that it also becomes the communicant.
\end{abstract}

Keywords: Educational Communication, Al-qur`an Surat Lukman 


\section{PENDAHULUAN}

Komunikasi sering kali dilakukan pada setiap aktivitas manusia, baik berkomunikasi dengan lisan, tertulis dan nonverbal. Begitupun juga dalam kegiatan organisasi tidak dapat terlepas dalam berkomunikasi, baik antara pimpinan dan bawahan ataupun antara bawahan itu sendiri dalam menyelesaikan tugas-tugas organisasi. Wahab (2008) mendefenisikan komunikasi organisasi sebagai pemahaman pesan diantara unit-unit komunikasi sebagai bagian dari suatu organisasi tertentu, maka yang menjadi unsur-unsur komunikasi adalah pengirim, pesan dan penerima pesan.Komunikasi sangat membantu dalam pekerjaan apapun. Salah melakukan komunikasi, maka akan berakibat fatal, yang sering diungkapkan dengan istilah misscomunication, yaitu kesalahan dalam menerima ataupun menyampaikan sebuah pesan. Salah dalam berkomunikasi akan membuat rumah tangga berantakan, atasan memarahi bawahan dan dapat terjadi konflik antar agama, ras suku dan sebagainya.

Interaksi guru dan siswa, sangatlah memerlukan komunikasi dalam penyampaian pesan, tentunya pendidik sebagai pengirim pesan-pesan moral dan ilmu pengetahuan kepada peserta didik yang menerima dan menelaah pesan yang disampaikan sehingga menjadi bekal bagi mereka dalam menjalankan kehidupan. Pemahaman pendidikan modern pendidik bukan lagi sumber utama pembelajaran tetapi peserta didik dapat mencari pengetahuan dari berbagai sumber seperti media elektronik ataupun media masa dan kecanggihan internet dan sebagainya. Komunikasi antara guru dan siswa bukan hanya satu arah tetapi dua arah, artinya siswa aktif dalam proses pembelajaran.

Komunikasi pendidikan tidak hanya berlangsung di sekolah, tetapi dirumah tangga sebagai fondasi awal pembentukan karakter dan kepribadian anak memerlukan komunikasi edukatif, orang tua sebagai landasan utama mengajarkan dan menanamkan kebaikan kepada anak. Seoorang anak dilahirkan dalam keadaan suci (fitrah), orang tua lah yang mengajarkan dan menyampaikan pesan-pesan edukatif kepada anak yang baru menghirup udara dunia, biasanya diperdengarkan dengan kalimat azan dan iqamah, dengan kalimat tersebut anak diperkenalkan dengan kalimat Allah sang pencipta muka bumi.

Seringkali komunikasi pendidikan dalam keluarga mengalami permasalahan, mungkin disebabkan oleh sibuknya orang tua dalam bekerja, lingkungan yang tidak mendukung ataupun pendidikan yang ditempuh oleh anak yang kurang berbasis pada penanaman nilai-nilai keagamaan. Tentunya ketauladanan ayah dan ibu dalam mendidik anak sangat diharapkan dalam memberikan pesan-pesan moral, terutama pendidikan keagamaan sebagai dasar dan pedoman bagi prilaku anak dalam proses perkembangannya. Apa yang diminum dan dimakan oleh anak harus jelas sumbernya dari jalan yang benar (halal), apalagi dilihat pola dan tingkah laku anak zaman 
ssekarang yang jauh dari norma-norma yang kita harapkan, hal ini sedikit banyaknya dipengaruhi oleh gagalnya membangun komunikasi dalam pendidikan keluarga.

Komunikasi pendidikan yang berjalan dengan baik akan mempengaruhi hasil pendidikan baik pada lingkungan keluarga, sekolah dan masyarakat. Dalam kasus komunikasi pendidikan dalam keluarga kita dapat melihat pada sosok Lukman yang namanya diabadikan dalam Alqur`an Surat Lukman. Beliau dianggap sebagai komunikator pendidikan dalam keluarga yang dapat dijadikan tauladan bagi kita dalam menanamkan ajaran-ajaran agama kepada generasi kita, walaupun beliau bukanlah sosok seorang Nabi. Shihab (2006) menyatakan bahwa hampir semua ulama sepakat bahwa Lukman bukanlah seorang Nabi, hanya sebagian kecil yang menyakan Lukman adalah Nabi.

Lukman adalah tokoh yang diperselisihkan identitasnya. Orang Arab hanya mengetahuil dua tokoh yang bernama Lukman.Pertama, Lukman Ibn`Ad. Tokoh ini berwibawa, kepemimpinan, ilmu, kefasihan dan kepandaianya.Ia kerap kali dijadikan sebagai permisalan dan perumpamaan. Tokoh kedua adalah Lukman al-Hakim yang terkenal dengan kata-kata bijak dan perumpamaan-perumpamaannya. Agaknya dialah yang yang dimaksudkan oleh surah ini. Lukman menyampaikan pesan dengan kasih sayang sebagaimana dipahami dari panggilan mesranya kepada anak. Kata bunnaya adalah patron yang mengambarkan kemungilan. Asalnya adalah ibny, dari kata ibn yakni anak laki-laki. Pemangilan mengisyaratkan kasih sayang, maka kita dapat berkata bahwa ayat di atas memberi isyarat bahwa mendidik hendaknya didasari oleh rasa kasih sayang (Shihab, 2006). Disamping materi akidah, materi pelajaran akhlak, perlu diajarkan agar peserta didik tidak jenuh dengan satu materi, tetapi juga untuk mengisyaratkan bahwa ajaran akidah dan akhlak tidak dapat dipisahkan (Shihab, 2006).

Realitas kehidupan sering kali pesan-pesan yang disampaikan oleh guru kepada siswa mengalami kegagalan, mungkin disebabkan metode yang diterapkan kurang tepat ataupun latar belakang pendidikan dan pengalaman pendidik yang minim sehingga proses penyampaian pesan moral tersebut mengalami kegagalan. Kecerdasan anak tidak cukup hanya kepada kecerdasan intelektual saja tetapi kecerdasan emosional dan spiritual sangat diharapkan. Kenakalan remaja, tawuran, mengkonsumsi narkoba, pemerkosaan merupakan gagalnya penanaman nilai-nilai spiritual, sehingga anak kehilangan jati diri dan figur yang harus ditauladani, anak merasa gersang dan tidak nyaman dalam kehidupan dilingkungan rumah tangganya yang kemudian mencari ketenangan yang sifatnya sesaat dan berdampak buruk kepada mental anak didik. Maka dari itu perlu komunikasi yang sifatnya edukatif dalam rumah tangga, sehingga terjalin suatu keharmonisan dan kenyamanan dalam rumah tangga kita. 


\section{METODE PENELITIAN}

Penelitian ini dirancang menggunakan pendekatan kualitatif dengan menerapkan metode penelitian kepustakaan (library research). Penelitian kepustakaan adalah penelitian yang data utamanya atau data pendukungnya diperoleh dari bahanbahan pustaka yang tersedia dan berkaitan dengan permasalahan yang diteliti

Data penelitian ini bersumber dari data primer dan sekunder, adapun yang menjadi data primer adalah Naskah Al-Qur`an Surat Lukman dan didukung dengan hadist-hadist Nabi yang relevan dengan permasalahan penelitian, sedangkan data sekunder bersumber dari buku-buku, majalah-majalah dan dokumen tertulis.Pada penelitian ini menggunakan dua cara yaitu, wawancara dan dokumentasi. Teknik dokumentasi hanya digunakan sebagai pelengkap data. Data yang diambil berupa data yang berhubungan dengan konsep komunikasi pendidikan dalam alqur`an surat Lukman.

Data penelitian didokumentasikan dalam rekaman, gambar, suara, tulisan, biasa dikenal dengan penelitian analisis dokumen atau analisis isi (content analysis). Dengan analisis isi ini peneliti bekerja dengan obyektif untuk mendiskripsikan bahan kajian komunikasi pendidikan dalam al-Qur`an Surat Lukma. Metode ini dimaksudkan untuk menganalisis konsep komunikasi pendidikan dalam kajian surat Lukman. Isi yang terkandung dalam pemikiran ini, kemudian dikelompokkan melalui tahap identifikasi, klasifikasi dan kategorisasi, kemudian dilanjutkan dengan interpretasi.

Untuk menetapkan keabsahan (trustworthiness) data diperlukan teknik pemeriksaan. Ada empat kreteria yang dapat digunakan untuk menguji keabsahan data, yaitu derajat kepercayaan (credibility), keteralihan (transferability), ketergantungan (dependability) dan kepastian akan data dan hasil penelitian. Keterlibatan peneliti sangat menentukan dalam pengumpulan data. Keterlibatan peneliti selama proses penelitian berlangsung. Disamping itu juga untuk menghilangkan "asing ditanah asing" pada diri peneliti dan menghilangkan keinginan responden untuk menyenangkan peneliti atau distorsi dari diri responden. Untuk menggali kedalaman data diperlukan ketekunan pengamatan.Pengamatan dilakukan secara mendalam pada setiap fokus penelitian.

Disamping itu juga dilakukan triangulasi. Trianggulasi yaitu pemeriksaan silang dari berbagai sumber yang digunakan. Triangulasi yang banyak digunakan adalah triangulasi dengan sumber yaitu crosscheck derajat kepercayaan suatu informasi yang diperoleh melalui waktu dan alat yang berbeda dalam penelitian. Lebih jelasnya tianggulasi dilakukan dengan jalan 1) mengkaji data hasil wawancara dengan hasil pengamatan, 2) mengkaji apa yang dikatakan orang di depan umum dengan apa yang dikatakan secara pribadi, 3) menelaah apa yang dikatakan orang tentang tentang situasi penelitian dengan apa yang dikatakan sepanjang waktu, 4) membandingkan 
keadaan dan perspektif seseorang dengan berbagai pandangan orang dari berbagai latar belakang, 5) mengkaji hasil wawancara deingan isi dokumen yang berkaitan. Trianggulasi dilakukan bersamaan dengan kegiatan pengamatan dilapangan, sehingga peneliti bisa melakukan pencatatan data secara lengkap.

Keteralihan sebagai persoalan empiris bergantung pada kesamaan antara konteks responden dan peneliti. Untuk melakukan pengalihan peneliti mencari dan mengumpulkan kejadian empiris tentang kesamaan konteks pada kejadian dilapangan, untuk membuat keputusan tentang pengalihan tersebut peneliti menyediakan data secukupnya. Hasil analisis sementara dalam penelitian ini selalu dikonfirmasikan baik kepada sumber data awal maupun dengan data baru yang diperoleh dari sumber lain. Untuk menyajikan agar data bermakna dan dapat dipahami. Maka langkah analisis data yang dilakukan adalah: pengumpulan data, reduksi data, penyajian data dan penarikan kesimpulan.

\section{HASIL DAN PEMBAHASAN}

\section{Interaksi Penyampai Pesan Pendidikan dalam al-Qur`an Surat Lukman}

Pada prinsipnya manusia mengadakan komunikasi dengan maksud untuk menyampaikan perasaan hatinya, pengalaman dirinya, rencana kerjanya atau pola tujuannya kepada orang lain (Pawit, 1990). Badeni (2009) menyatakan bahwa komunikasi merupakan proses penyampaian pesan berupa gagasan, fakta, pikiran atau perasaan dari satu orang kepada orang lain. Proses penyampaian pesan, ide, gagasan dan fakta tersebut diperankan oleh seorang sender sebagai pengirim pesan kepada penerima pesan. Penyampai pesan (sender) adalah seseorang yang memiliki gagasan, maksud, informasi dan tujuan untuk berkomunikasi (Gibson, 1985).

Lukman sebagai sosok penyampai pesan mengungkapkapkan, menyampaikan atau membagi pengalaman dirinya kepada anaknya sebagai wujud syukur beliau kepada Allah SWT. Menurut Shihab (2006) menyatakan bahwa Lukman mendapatkan anugrah dari Allah SWT atas kesukuran dan pengenalan terhadapNya yang kemudian dilestarikan kepada generasinya dan kemudian siapa saja diperintahkan untuk merenungkan anugerah Allah kepada Lukman itu dan mengingat serta mengingatkan orang lain. Wujud kesyukuran Lukman kepada Allah yang kemudian beliau aplikasikan kepada anaknya dapat dijadikan cerminan bagi kita umat manusia, terutama pendidik dalam mendidik generasi selanjutnya.Peran orang tua sebagai wujud syukur yang telah dianugrahkan Allah keturunan dan menjadi amanah bagi kita untuk memlihara, mendidik dan menyayangi mereka.

\section{Peran Orang Tua}

Pada kebanyakan keluarga, peranan ibu sangat penting terhadap anak-anaknya. Sejak anak lahir ke dunia, ibulah selalu berada disampingnya, memberi makan dan 
minum, memelihara dan selalu bercampur gaul dengan anak-anak. Kebanyakan anak sangat sayang kepada ibunya diantara keluarga lainnya. Menurut Shihab (2006) mengambarkan begitu besar jasa ibu kepada anaknya dengan mengartikan kata wahnan yang artinya kelemahan atau kerapuhan, yang dimaksud disini memikul beban kehamilan, menyusui dan pemeliharaan anak, maka dalam konteks melahirkan anak, beban ibu lebih berat dibandingkan bapak, hal ini dapat kita lihat dari proses pembuahan sampai anak lahir ke dunia beban ini dipikul sendiri oleh ibu, tidak cukup sampai masa kelahiran, tetapi berlanjut dengan penyusuan dan sampai anak dewasa. Memang ayahmembantu ibu, agar beban yang dipikulnya tidak terlalu berat, namun hal ini tidak bersentuhan dengan anak secara langsung. Betapapun peranan bapak tidak sebesat peranann ibu dalam proses kelahiran anak, namun jasa bapak tidak diabaikan karen itu anak berkewajiban berdoa untuk ayahnya, sebagaimana berdoa untuk ibunya.

Betapa berat beban ibu sebagi pendidik bagi anak dan sekaligus mengatur rumah tangga. Dampak didikan ibu terhadap anakakan berpengaruh besar terhadap perkembangan dan watak anaknya dikemudian hari. Seorang ibu yang selalu khawatir dan selalu menurutkan keingianan anak-anaknya, berdampak negative terhadap perkembangan anak.Kemudian tidak baik juga, jikalau ibu berlebih-lebihan mencurahkan perhatian kepada anaknya. Asalkan segala pernyataan disertai rasa kasih sayang yang terkandung dalam hati ibunya, anak itu dengan mudah akan tunduk kepada pemimpinnya.

Ayahpun memegang peranan yang penting pula dalam pertumbuhan dan perkembangan anak. Anak memandang ayahnya sebagai teladan bagi dirinya. Prilaku ayah sehari-hari sangat berpengaruh terhadap prilaku anaknya, lebih-lebih anak yang telah besar, sepatutnyalah anak bersyukur kepada kedua orang tuanya. Hamka (1982) menyatakan bahwa syukur paling utama adalah kepada Allah karena semuanya itu, sejak masa kehamilan sampai mengasuh dan mendidik dengan tidak ada rasa bosan, dipenuhi rasa cintah dan kasih adalah berkat Rahmat Allah belaka. Kemudian bersyukur kepada kedua orang tuamu, ibu yang mengasuh dan ayah yang membela dan melindungi ibu, anak-anaknya dan berusaha mencari sandang dan pangan setiap hari.

Meskipun demikian dibeberapa keluarga masih dapat kita lihat kesalahankesalahan pendidikan yang diakibatkan oleh tindakan seorang ayah. Karena orang tua sibuk bekerja mencari nafkah, sehingga ayah tidak sempat untuk bergaul dengan anak-anaknya.Lebih celaka lagi seorang ayah yang sengaja tidak mau berurusan dengan pendidikan anak-anaknya. Ia mencari kesenangan bagi dirinya sendiri saja. Segala kekurangan yang terdapat di dalam rumah tangga mengenai pendidikan anakanaknya dibebankan kepada istrinya, dituduhnya dan dimaki-maki istrinya. 
Selain pendidikan dari orang tua, banyak anak menerima pendidikan dari nenek dan kakeknya. Umumnya nenek sering mencurahkan kasih sayang yang begitu besar kepada cucu-cucunya. Mereka tidak mengaharapkan sesuatu dari cucu-cucunya, mereka semata-mata memberi kasih sayang yang tulus, sehingga sering memanjakan cucu-cucunya dengan sangat berlebih lebihan.

Dalam suatu keluarga serumah dengan nenek, sering kali terjadi pertengkaran atau perselisihan antara orang tua anak dan nenek mengenai cara mendidik anakanaknya. Pandangan orang tua anak tentang mendidik anaknya sering bertentangan dengan pandangan nenek yang merasa bahwa si nenek itu sudah lebih banyak "makan garam" dari pada anaknya (orang tua anak itu). Berdasarkan pengalaman, orang dapat mengetahui bahwa untuk kepentingan pendidikan anak-anaknya sering lebih baik jika keluarga itu tinggal terpisah dari nenek. Kunjungan nenek yang sewaktu-waktu dan bermalam sekali-kali di rumah orang tua anak telah cukup untuk menyenangkan hati anak.

\section{Peran Guru}

Lukman adalah sosok orang tua yang memberi nasehat kepada anaknya dengan lemah lembut dan penuh dengan kasih sayang, sehingga materi yang disampaikan dapat diterima dengan mudah dan dapat dipahami oleh anak dalam menjalankan kehidupannya. Setidaknya sosok lukman tersebut dapat tercermin juga kepada tenaga pendidik (guru) kita dalam menjalankan amanahnya. Rosyada (2007) tenaga pendidik harus berkompeten dalam bidang ilmu yang diajarkan, kemudian memiliki kemampuan teoritis, dan memiliki loyalitas keguruan.

Kemudian Uno (2007) tenaga pendidik bertanggungjawab mendidik, mengajar dan membimbing peserta didik. Orang yang disebut guru adalah orang yang memiliki kemampuan merancang program pembelajaran serta mampu menata dan mengelola kelas agar peserta didik dapat belajar dan pada akhirnya dapat mencapai tingkat kedewasaan sebagai tujuan akhir dari proses pendidikan.

Guru memiliki andil terhadap keberhasilan pembelajaran di sekolah. Guru membantukeberhasilan peserta didik dalam mencapai tujuan hidupnya secara optimal. Kusuma (2009) menyatakan tenaga pendidik adalah agent of change dan pendidik karakter. Mulyasa (2008) menyebutkan peran guru terhadap perkembangan peserta didik antara lain sebagai berikut: 1) guru sebagai pendidik, 2) guru sebagai pengajar, 3) guru sebagai pembimbing, 4) guru sebagai pelatih, 5) guru sebagai penasehat, 6) guru sebagai pembaharu, 7) guru sebagai model dan teladan, 8) guru sebagai pribadi, 9) guru sebagai peneliti, 10) guru sebagai pendorong kreativitas, 11) guru sebagai pembangkit pandangan, 12) guru sebagai pekerja rutin, 13) guru sebagai pemindah kemah, 14) guru sebagai pembawa cerita, 15) guru sebagai actor, 16) guru sebagai 
emancipator, 17) guru sebagai evaluator, 18) guru sebagai pengwet dan 19) guru sebagai kulminator.

\section{Isi Pesan}

Pesan adalah serangkaian isyarat atau simbol yang diciptakan oleh manusia untuk saluran tertentu, dengan harapan bahwa pesan itu akan mengutarakan atau menimbulkan suatu makna tertentu dalam diri orang lain yang hendak diajak berkomunikasi (Pawit, 1990). Gibson (1985) menyatakan bahwa pesan adalah berita yang dapat disampaikan oleh komunikator kepada penerima dan bergantung pada perantara atau media yang dipakai untuk menyampaikan pesan tadi. Isi pesan Lukman kepada anaknya antara lain: a) tidak mempersekutukan Allah, karena hal tersebut perbuatan zalim, b) menghoramti kedua orang tua, c) berlaku baik walau sekecil apapun, d) mendirikan sholat dan e) tidak berlaku sombong dalam kehidupan di muka bumi. Pesan-pesan tersebut diharapkan bermakna dan bermanfaat bagi penerima pesan dalam hal ini generasi kita dalam menjalankan kehidupan di muka bumi.

\section{Tidak Berlaku Syirik}

Lukman menekankan agar tidak berlaku syirik. Larangan ini sekaligus mengandung pengajaran tentang wujud dan keesaan Tuhan. Redaksi pesannya berbentuk larangan, jangan mempersekutukan Allah untuk menekan perlunya meninggalkan sesuatu yang buruk sebelum melaksanakan yang baik. Diantara yang menarik dari pesan ini adalah bahwa pesan disertai dengan argumen "Jangan mempersekutukan Allah, sesungguhnya mempersekutukanNya adalah penganiyayaan besar". Demikianlah seharusnya materi petunjuk atau materi pendidikan yang disajikan ini dibuktikan kebenarannya dengan argumentasi yang dipaparkan atau yang dapat dibuktikan oleh manusia melalui penalaran akalnya (Shihab, 2006)

Pesan ini berbentuk larangan untuk mempersekutukan Allah, berdasarkan argumen yang jelas bahwa mempersekutukan Allah adalah penganiyayaan besar bagi dirinya sendiri dengan harapan bahwa pesan itu akan mengutarakan atau menimbulkan suatu makna tertentu dalam diri orang yang menerima pesan. Pesan Lukman diawali dengan sifat ketauhidan yakni menjelaskan bahwa berlaku syirik adalah perbuatan yang zalim dan aniyaya terhadap diri sendiri. Penanaman nilai ketauhidan orang tua yang pertama kali terhadap anak dalam kelahirannya adalah memperkenalkan nama Allah, yang dikumandangkan suara Azan ditelinga kanan dan Iqamah ditelinga kiri. Rohimin (2008) menyatakan bahwa fase utama pendidikan anak adalah pada fase anak usia dini. 
Pada fase ini anak perlu diberikan rangsangan pendidikan untuk membantu pertumbuhan dan perkembangannya. Pada fase usia dini adalah hal yang sangat tepat dalam menanamkan nilai-nilai ketauhidan, sering terjadi anak-anak yang kritis bertanya tentang sesuatu yang membingungkan orang tua dalam menjawabnya seperti tentang keberadaan Tuhan, hal ini akan berbahaya jikalau orang tua tidak mampu memberikan penjelasan yang jelas kepada anak. Maka dari itu penanaman nilai ketauhidan hendaknya diajarkan pad fase anak usia dini sebagai landasan dan fondasi yang kuat dalam berpegang teguh terhadap keyakinan dan ajaran agamanya.

\section{Mentaati Perintah Kedua Orang Tua}

Pesan yang selanjutnya adalah mentaati perintah kedua orang tua yang telah mendidik, membimbing dan memelihara kita hingga kita tumbuh menjadi dewasa. Tuhan memerintahkan kepada manusia untuk menghormati orang tua, sebab restu dan ridho orang tua manusia dilahirkan ke muka bumi(Hamka, 1982). Bersyukurlah kamu kepada Allah dan kepada kedua orang tuamu. Syukur pertama ialah kepada Allah, setelah itu bersyukurlah kepada kedua orang tuamu (Hamka, 1982).

Pesan ini mengajarkan bahwa, apabila dalam urusan agama orang tua membelot dari agama Allah, maka kita sebagai anak boleh tidak mengikutinya tetapi kita masih mempergaulinya dengan baik sellaku orang tua. Menurut Shihab (2006) menyatakan bahwa dalam persoalan agama, hendaklah engkau mengikutinya jalan kedua orang tuamu itu.Tetapi kalau tidak demikian, maka ikutilah jalan selain mereka yaitu jalan orang-orang yang kembali kepada Allah. Dengan demikian kata ad-dunya mengandung pesan, pertama bahwa mempergauli dengan baik itu hanya dalam urusan kedunian, bukan keagamaan. kedua, bertujuan meringankan beban tugas itu, karena ia hany untuk sementara yakni selama hidup di dunia yang hari-harinya terbatas, sehingga tidak mengepalah memikul beban kebaktian kepadaNya dan yang ketiga bertujuan memperhadapkan kata dunia dengan hari kembali kepada Allah yang dinyatakan di atas dengan kalimat hanya kepadaKu kembali kamu.

\section{Berlaku Baik Walau Sekecil Apapun}

Pesan Lukman kepada anaknya, yang kali ini diuraikan adalah kedalaman ilmu Allah SWT, yang diisyaratkan pula oleh penutup ayat lalu dengan pernyataaNya: “....maka Ku-beritakan kepada kamu apa yang telah kamu kerjakan”. Lukman berkata: "Wahai anakku, sesungguhnya jika ada sesuatu perbuatan baik atau buruk walau seberat biji sawi yang tersembunyi, atau di langit yang demikian, niscaya Allah akan memperhitungkan dan memberinya balasan, maka pesan kali ini mengambarkan Kuasa Allah melakukan perhitungan atas amal-amal perbuatan manusia di akhirat nanti. 


\section{Mendirikan Sholat}

Lukman melanjutkan nasehatnya kepada anaknya nasehat yang dapat menjamin kesinambungan Tauhid serta kehadiran Ilahi. Beliau berkata Wahai anakku kerjakan shalat, kerjakan ma`ruf dan jauhi kemungkaran.Banyak tantangan dan rintangan dalam melaksanakan perintah Allah, tabah dan bersabarlah dalam melaksanakan tugasmu. Nasehat Lukman di atas menyangkut hal-hal yang berkaitan dengan amalamal saleh yang puncaknya adalah shalat, serta amal-amal kebajikan yang tercermin dalam amar màruf dan nahi munkar, juga nasehat berupa perisai yang membentenginya seseorang dari kegagalan yaitu sabar dan tabah. Inilah empat modal hidup diberikan Lukman kepada anaknya dan dibawakan menjadi modal pula bagi kita semua, disampaikan oleh Muhammad kepada umatnya.Lukman tidak memerintahkan anaknya melaksanakan ma`ruf dan menjauhi mungkar, tetapi memerintahkan, menyuruh dan mencegah. Disisi lain membiasakan anak melaksanakan tuntunan ini menimbulkan dalam dirinya jiwa kepemimpinan serta kepedulian sosial (Shihab, 2006).

\section{Tidak Berlaku Sombong dalam Kehidupan di Muka Bumi}

Nasehat Lukman kali ini berkaitan dengan akhlak dan sopan santun berinteraksi dengan sesama manusia. Beliau menasehatinya anaknya dengan berkata: dan wahai anakku, disamping butir-butir nasehat yang lalu, janganlah juga engkau berkeras memalingkan pipimu yakni mukamu dari manusia siapapun dia didorong oleh penghinaan dan kesombongan. Tetapi tampillah kepada setiap orang dengan wajah berseri penuh rendah hati. Bersikap sederhanalah dalam berjalanmu, yakni jangan membusungkan dada dan jangan juga merunduk bagaikan orang sakit. Jangan berlari tergesa-gesa dan jangan juga sangat perlahan menghabiskan waktu. Dan lunakanlah suaramu sehingga tidak terdengar kasar bagaikan teriakan keledai. Sesungguhnya seburuk-buruk suara ialah suara keledai karena awalnya siulan yang tidak menarik dan akhirnya tarikan nafas yang buruk.

\section{Media Pesan}

Media berasal dari kata medium (media: jamak, medium: tunggal) artinya secara harfiah adalah perantara, penyampai atau penyalur (Pawit, 1990). Gibson (1985) mendefenisikan media adalah alat untuk menyampaikan pesan. Badeni (2009) media adalah sarana untuk menyampaikan pesan, informasi, pikiran atau perasaan dari satu orang ke orang lain. Saluran atau media itu dapat berupa mata, pendengaran atau perabaan. Lebih jauh, karena komunikasi terjadi dalam berbagai bentuk, terdapat banyak saluran atau media komunikasi yang terjadi dalam setiap konteks komunikasi, misalnya saluran atau media tatap muka, telepon dan surat menyurat. 
Lukman menyampaikan pesan dengan menggunakan media panca indera, "Dan lihatlah ketika Lukman berkata kepada anaknya.....", "wahai anakku, sesungguhnya jika ada seberat biji sawi dan berada dalam batu karang atau di langit......".Lukman memulai nasehat dengan anaknya pertama kali dengan menyampaikan konsep ketauhidan dan kemudian dibarengi dengan penanaman nilai akidah.Dengan tegas lukman menyampaikan pesan larangan untuk tidak mempersekutukan Allah karena mempersekutukanNya adalah perbuatan yang zalim.

Pesan, informasi, pikiran dan perasaan Lukman yang disampaikan kepada anaknya, merupakan wujud syukur beliau kepada Allah SWT yang tercermin pada pengenalan terhadapNya dan anugerahNya. Pengalaman hikmah itu dilukiskan dan diaplikasikan kepada anak dalam menjalankan hidup di muka bumi ini. Maka dari itu wajib bagi orang tua untuk menyampaikan pesan-pesan tauhid dan akhlak kepada anakya sebagai wujud syukur kita kepada Allah SWT, karena anak adalah titipan Allah, sehingga kita berkewajiban mendidik, memelihara dan membesarkanya dalam keadaan baik, apabila kita melalaikan itu, berarti kita tidak menjaga amanah Allah, maka kita termasuk orang yang tidak bersyukur atas karuniaNya.

\section{Makna Konsep Komunikasi Pendidikan dalam Al-Qur`an Surat Lukman}

Agar proses komunikasi dapat berlangsung dengan baik, pesan itu harus disandikan sesuai dengan penerima. Penguraian sandi adalah istilah teknis bagi proses pemikiran penerima (Gibson, 1985). Dalam hal ini yang menjadi penerima pesan adalah seorang anak, bagaimana anak menafsirkan dan menguraikan pesan yang disampaikan oleh orang tuanya atau guru yang sesuai dengan pengalaman dan kerangka acuan mereka.

Anak dalam urusan aqidah boleh membantah apabila tidak sejalan lagi dengan orang tuanya dalam berpeguh teguh pada keyakinan, tetapi dalam kategori yang sopan dan santun. Shihab (2006) menjelaskan bahwa jika kedua orang tuamu termasuk orang yang senang kembali kepada Allah (mengikuti ajaranNya) maka hendaklah engkau mengikuti jalan kedua orang tuamu, tetapi kalau tidak demikian, maka ikutilah jalan selain mereka yaitu jalan orang-orang yang kembali kepada Allah.

Hamka (1982) menjelaskan dalam tafsirnya Alzhar bahwa satu waktu seorang anak yang setia kepada orang tuanya, tiba-tiba kedua orang tuanya memaksa untuk berbuat syirik kepada Allah dengan tegas ayat menyatakan bahwa "jangan engkau ikuti keduanya", tentu timbul pertanyaan, apakah si anak mendurhakai orang tuanya, jawabnya diteruskan pada ayat lanjutan "Dan pergaulilah keduanya di dunia ini dengan sepatutnya". Artinya ialah bahwa keduanya selalu dihormati, disayangi, dicintai dengan sepatutnya dengan yang ma`ruf. Jangan mereka dicaci dan dihina, 
melainkan tunjukkan saja bahwa dalam hal akidah memang berbeda akidah engkau dengan beliau.

Sebagai anak boleh membantah kalau memang tidak sesuai dengan apa yang kita yakini dan kita alami, tetapi dalam kategori yang sopan dan santun dan kemudian kita telaah dan pelajari pesan yang disampaikan itu sesuai atau tidak dengan apa yang kita yakini dan kita alami sehingga, tidak menyimpang dari ajaran agama yang kita yakini, atau sebagai anak boleh mengingatkan orang tuanya (feed back) jikalau orang tua lupa dan salah, tetapi dalam penyampainnya menggunakan metode yang tepat dan logis, sehingga orang tua tidak tersinggung dalam menerimanya.

Maka makna konsep komunikasi pendidikan dalam al-Qur’an surat lukman adalah makna konsep komunikasi yang sifatnya aplikatif yang perlu diterapkan oleh orang tua ataupun guru sebagai pendidik dan penyampai pesan dengan mengambil pelajaran dari kisah Lukman dalam al-Quran sebagai orang tua dalam mengajarkan kepada anaknya.

\section{SIMPULAN}

Simpulan penelitian ini secara umum tentang konsep komunikasi pendidikan dalam surat Lukman adalah proses dialogis antara sosok Lukman sebagai seorang ayah dengan anaknya dalam upaya untuk mencapai keselamatan hidup di dunia maupun di akhirat. Istilah proses dialogis disini menunjukkan bahwa adanya suatu unsur komunikasi antara dua orang, dalam hal ini antara ayah dengan anak. Ayah berkedudukan sebagai komunikator atau pemakarsa gagasan dalam merencanakan suasana dialog tersebut. Lukman sebagai sosok ayah yang memberi nasehat kepada anaknya sebagaimana dapat dipahami dari kata (يعظه) ya`izzhuhu terambil dari kata (وعظ) wa`zh yaitu nasehat menyangkut berbagai kebijakan dengan cara menyentuh hati. Namun juga ia sekaligus merupakan pihak yang mendengarkan (dalam umpan balik dialog) sehingga ia sekaligus menjadi komunikan. Komunikator dan komunikan (ayah dan anak) secara bersama-sama terlibat dalam suasana komunikasi. Mereka melakukan berbagai gagasan, ide atau pendapat dan berbagai informasi yang dipunyai masing-masing.

Simpulan penelitian ini secara khusus sebagai berikut: Pertama, interaksi penyampai pesan (komunikator) dalam penelitian ini adalah interaksi antara sosok Lukman sebagai orang tua yang selalu bersyukur kepada Allah sehingga ia mendapat hikmah dari Tuhan dan kemudian dilestarikan pengalamannya tersebut kepada anaknya, hal ini dapat dipahami dari kata (بني) bunnaya adalah patron yang mengambarkan kemungilan, asalnya adalah (ابني) ibny, dari kata (ابن) ibn yakni anak lelaki. Pemungilan tersebut mengisyaratkan kasih sayang, artinya interaksi antara Lukman dengan anakya berdasarkan kasih sayang, sehingga pesan yang disampaikan dapat diterima dengan baik oleh anak. 
Kedua, isi pesan pendidikan dalam al-Qur`an Surat Lukman adalah penanaman nilai ketahuidan dan akhlak, seperti tidak berlaku syirik (لله با لاتثرك), taat kepada

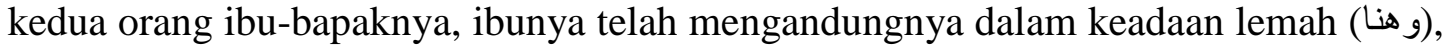
mendirikan sholat (الصلاه اقم), berbuat baik walau sekecil apapun dan tidak berlaku sombong dalam kehidupan di muka bumi. Ketiga, media pesan yang disampaikan melalui sosok Lukman sebagai orang tua yang selalu memberikan nasehat-nasehat kepada anaknya dengan lemah lembut dan kasih sayang, sehingga anak dengan mudah memahami pesan yang disampaikan. Keempat, makna konsep komunikasi pendidikan dalam al-Qur`an surat Lukman adalah sosok Lukman yang digambarkan dalam al-Qur`an dalam mendidik anaknya yang dapat dijadikan rujukan dan contoh bagi orang tua ataupun guru dalam mendidik anak, Lukman mendidik anaknya dengan ketauladanan dan kasih sayang, tidak dengan membentak ataupun dengan kekerasan, sehingga pesan yang disampaikan dapat diterima oleh anak dengan baik. 


\section{DAFTAR PUSTAKA}

Badeni, B. (2009). Kepemimpinan dan Prilaku Organisasi. Bengkulu: Program Studi Magister Manajemen Pendidikan Universitas Bengkulu

Mulyasa, E. (2008). Menjadi Guru Profesional. Bandung: PT Remaja Rosdakarya

Gibson, G. (1985). Prilaku Organisasi. Jakarta: PT Erlangga

Hamka, H. (1982). Tafsir Al-Azhar. Pustaka Nasional

Uno, H. B.(2007). Profesi Kependidikan. Jakarta: Bumi Aksara

Kusuma, D. (2009). Pendidik Karakter. Jakarta: Grafindo Persada.

Pawit, M. (1990). Komunikasi Pendidikan dan Komunikasi Instruksional. Bandung: PT Remaja Rosdakarya.

Rohimin, R. (2008). Tafsir Tarbawi (Kajian Analitis dan Penerapan Ayat-ayat Pendidikan). Yogyakarta: PT Nusa Media

Rosyada, D. (2007). Paradigma Pendidikan Demokratis: Jakarta: Kencana Prenada Media Group

Shihab, M. Q. (2006). Tafsir Al-Mishbah. Jakarta: Penerbit Lantera Hati

Wahab, A. Z. (2008). Anatomi Organisasi dan Kepemimpinan Pendidikan. Bandung: Penerbit Alfabeta 